\title{
Recenzja: Katarzyna Wrzesińska, Kultura i cywilizacja w myśli Narodowej Demokracji (1893-1918). Między ideą wychowania a polityką, Warszawa: Instytut Slawistyki PAN, Fundacja Slawistyczna 2012, ss. 377.
}

\author{
Grzegorz Krzywiec
}

\begin{abstract}
Abstrakt: Książka Katarzyny Wrzesińskiej, historyczki idei oraz polskiej myśli politycznej w XIX i XX wieku, związanej z Instytutem Slawistyki PAN, stawia sobie ambitny cel: omówienie polityki kulturowej Narodowej Demokracji, największego ruchu politycznego na ziemiach polskich przełomu XIX i XX stulecia. Książka porusza kwestię definicji „narodu” $i$ „ludu” w nacjonalistycznej ramie pojęciowej, roli pomysłów edukacyjnych w szerszym spektrum projektu nacjonalistycznego oraz wpływu nacjonalistycznych idei na polską inteligencję. K. Wrzesińska nie odnosi się do obecnie toczącej się w naukach społecznych debaty dotyczącej definicji i rozumienia nacjonalizmu w literaturze, decyduje się zupełnie pominąć tę dyskusję. Bez wątpienia nowa rama teoretyczna pozwoliłaby rozwinąć studia nad polskim nacjonalizmem. Paradoksalnie jednak, chociaż autorka analizuje szeroki zestaw publikowanych już, podstawowych dokumentów, na koniec oferuje dobrze znaną i konwencjonalną opowieść o „młodych idealistach”, z czasem uformowanych przez masową politykę lub przez masy jako takie. Retoryka nacjonalizmu jest sama w sobie wystarczająco zrozumiała, jednak w obrazie stworzonym przez Wrzesińską nie jest oczywiste, w jaki sposób nacjonalistyczne słownictwo i idee zostały powszechnie przejęte i wykorzystane. Autorka tworzy za to kolejną wymijającą opowieść o niewinnej i kulturalnej nacji oraz - przede wszystkim - o jej elicie, napastowanej przez brutalnych i niecywilizowanych przeciwników. Epistemologiczna naiwność, nadmiar niezanalizowanych cytatów oraz wąski zestaw pytań badawczych nie pozwalają w pełni przedstawić przyczyn i sposobu, w jaki polski integralny nacjonalizm różnił się od innych nacjonalistycznych nurtów epoki.

Niestety książka nie pomaga zrozumieć złożoności sytuacji Narodowej Demokracji w polskiej historii omawianego okresu. Nie tylko w niewystarczający sposób poszerza naszą wiedzę, lecz również blokuje poważne pytania na temat tego ruchu i jego toksycznej spuścizny.

Wyrażenia kluczowe: polityka kulturowa; Narodowa Demokracja; polski nacjonalizm; polityka mas
\end{abstract}

Praca Katarzyny Wrzesińskiej, historyczki idei związanej z Instytutem Slawistyki PAN, Kultura i cywilizacja w myśli Narodowej Demokracji (1893-1918). Między idea wychowania a polityką składa się z dziewięciu rozdziałów, poprzedzonych wstępem, z czego rozdział pierwszy ma charakter metodologicznego wprowadzenia. Rozdział drugi (Przemiany doby przełomu. O duchu epoki i pokoleniu niepokornych raz jeszcze) jest ogólnym rysem epoki; trzeci - próbą opisania kluczowych, zdaniem autorki, pojęć z wokabularza narodowych demokratów (Cywilizacja i kultura. Podstawowe pojęcia pojmowania dziejów); czwarty i piąty - próbą zmierzenia się z definicjami narodu i ludu (Czym jest naród oraz Lud jako podstawa siły narodowej); rozdział szósty - czymś, co można chyba określić jako próbę wytłumaczenia ewolucji Narodowej Demokracji (Idea wychowywania - od humanistycznego przesilenia do „endeckiej mentalności”). W rozdziałach siódmym i ósmym autorka starała się zdiagnozować fenomen zainteresowania nacjonalizmem wśród inteligencji twórczej, a także narodzinami geopolitycznych wyborów grupy (W kręgu narodowych muz oraz Rosja i Niemcy a sprawa polska). Ostatni, dziewiąty rozdział to przedstawienie stosunku narodowych demokratów do grup etnicznie niepolskich (Państwo polskie 
a mniejszości narodowe w kontekście cywilizacyjno-kulturowych wyobrażeń o kształtowaniu się narodowości). Książka zawiera zakończenie, bibliografię i indeks nazwisk.

Problematyka rozprawy została zdiagnozowana trafnie i przekonywająco. Przeprowadzenie analizy pojęć „kultury” i „cywilizacji”, a także projektów wychowawczych w tradycji endeckiej byłoby chyba najbardziej obiecującym zamierzeniem pracy. Wiedza na temat Narodowej Demokracji - nie tylko wśród historyków - jest bowiem nierówna i pełna luk. Z pewnością żadna z dotychczasowych interpretacji nie zdołała wprost, całkowicie przedstawić szerokiego obszaru zainteresowań tej grupy.

Praca rzucająca nowe światło na początki formacji, jak i całego przesilenia ideowego, jest jak najbardziej potrzebna, a propozycję całościowego odczytania należy uznać ze wszech miar za cenną.

Czy polscy nacjonaliści z przełomu wieków dobrze sobie radzili z identyfikowaniem problemów otaczającego świata? Czy mieli coś istotnego do zaproponowania? Śmiem twierdzić, że ich projekt był odpowiedzią na rzeczywiste potrzeby, dla wielu też stanowił odpowiedź atrakcyjną. Liczne grupy społeczne dostrzegły w nim potencjał do zmiany, czasami ucieleśniał wręcz nadzieje na nową epokę w polskiej polityce; co więcej, o jego atrakcyjności może świadczyć trwała, kulturowa obecność poszczególnych elementów aż do czasów współczesnych. Tyle, że z pracy Katarzyny Wrzesińskiej wcale to nie wynika.

Autorka w zasadzie pomija nie tylko cały terminologiczny sztafaż obecny we współczesnej literaturze o nacjonalizmie, ale też większość debat w naukach społecznych dotyczących tego skądinąd żywo dyskutowanego problemu. Na pierwszy rzut oka można by uznać, że w ten sposób dąży do oczyszczenia przedpola interpretacyjnego i przygotowuje uzasadnienie dla własnego podejścia badawczego. Jednak biorąc w nawias dotychczasowe sądy w literaturze, autorka nie jest aż taka „metodologicznie cnotliwa”, jak by można z początku sądzić.

W pracy pojawiają się obiegowe stwierdzenia i hasła ideologiczne dotyczące takich zagadnień, jak „egoizm narodowy” czy „interes narodowy”, na prawach analitycznych definicji. Nawet same pojęcia „cywilizacja” i „kultura”, tak istotne dla rozprawy, są przyjęte niemal arbitralnie i większości wypadków bezkrytycznie zaaplikowane do odczytania zgodnie z twórczością rodzimych nacjonalistów. Wszystkie te kategorie w kulturze umysłowej Europy tego czasu, jak i później, nie były i nie są przecież neutralne znaczeniowo, a wręcz przeciwnie, za każdym razem nacechowane były i są ideologią. Za dobrą monetę bierze więc Wrzesińska nacjonalistyczne slogany mobilizacyjne w rodzaju „pomnażania energii na polu społecznym”, „solidaryzmu narodowego” czy „narodowego stanu posiadania".

Oczywiście, żeby rozumieć, co tak naprawdę znaczyły te pojęcia, trzeba by było prześledzić ich kulturowe genealogie $w$ debacie publicznej; przydało by się także zestawienie $z$ innymi nacjonalizmami epoki. Integralny nacjonalizm przełomu wieku nie był przecież zjawiskiem osobliwie polskim.

SLH 3/4 2014/2015 | str. 306 
Przez cały wywód autorka niestety nie zdołała się ustrzec sądów o charakterze, mówiąc łagodnie, ogólnikowym. Być może ten zalew pustej frazeologii, katachrezy, jest w sumie najtrudniejszy do strawienia przy lekturze tej pracy. Także procedura interpretacyjna może budzić wątpliwości, bowiem w przeważającej większości wypadków sprowadza się do streszczeń tekstów, czasem wręcz niezachowujących ich przesłania, lub parafraz.

Ma to znaczenie, jeśli tak dużą rolę w pracy odgrywa cytat. Na tyle dużą, że co bardziej systematyczny czytelnik po pewnym czasie dochodzi do wniosku, że granice między cytowanymi fragmentami a własnym komentarzem autorki zostały zachwiane. Niektóre ustępy aż proszą się o bardziej interpretacyjny komentarz usytuowany w dodatkowym kontekście. Inne wręcz zachęcają nie tylko do odczytania, ale sprawiają wrażenie niedoczytania. Często padają kwieciste frazy w rodzaju: „w zniewolonej Polsce najwyższą wartością było słowo, w tym sensie, że tylko ono mogło przekazać ciągłość wolnościowej idei” (Wrzesińska, 2012, s. 216). Zaraz potem autorka dodaje: „rodziła się polska inteligencja, zrywająca z dotychczasową biernością rodziców i poprzez konspirującą działalność protestująca przeciwko niewoli” (Wrzesińska, 2012, s. 216). Tego typu okrągłe i hiperboliczne, w sumie zaś nic niemówiące sformułowania powtarzają się w całym tekście. Jakby tego było mało, kilka stron dalej autorka dodaje: „dysponując ograniczonymi formami działania i chcąc je do końca wykorzystać, młode pokolenie zwróciło uwagę na dziedziny mające za patronki greckie muzy” (Wrzesińska, 2012, s. 221). Czasami cytowanie całych ustępów ma sens, ale zazwyczaj jest po prostu manieryczne.

Dosyć meandrycznie prezentuje autorka stanowisko środowiska nacjonalistycznego w kwestii narodu, choć to w książce wyodrębniony rozdział. Wraz z jej upodobaniem do frazesu daje to, niestety, efekt niezbyt szczęśliwy. O endeckiej koncepcji narodu Wrzesińska pisze na przykład: „ich koncepcja narodu silnie była zakorzeniona w dziedzictwie cywilizacji zachodniej, do której zaliczano Niemcy. Poczucie przynależności do Europy wywarło decydujące piętno na całokształcie ideologii narodowodemokratycznej" (Wrzesińska, 2012, s. 248). Chwile potem autorka dodaje, że endecja w czasie niewoli „niemal bezkrytycznie podchodziła do zjawisk współtworzących cywilizację Europy Zachodniej” (Wrzesińska, 2012, s. 248). Gdzie indziej, wskazuje zaś, że „dla narodowych demokratów, zarówno w sferze duchowej, jak i w odniesieniu do realiów politycznych, największą wartość stanowiła wolność" (Wrzesińska, 2012, s. 257).

Zaskakująco rzadko autorka sięga zwłaszcza do dorobku warszawskiego tygodnika „Głos”; pisma, które nie tylko w dużej mierze ukształtowało pierwsze pokolenie polskich nacjonalistów, ale dawało też przegląd opinii ówczesnej radykalnej inteligencji na temat wyobrażeń narodu. Na tę ciągłość zwracali uwagę nie tylko poprzednicy autorki, rozliczni pamiętnikarze, ale przede wszystkim sami założyciele Narodowej Demokracji. Nie trzeba wielkiej inwencji, żeby uznać, że późniejsza ewolucja endecji w tej dziedzinie, to $w$ dużej mierze rozwinięcie części pomysłów, które pojawiły się na przełomie lat osiemdziesiątych i dziewięćdziesiątych XIX wieku. 
Dlaczego jest to istotne? I tu być może dociera się do sedna jednego z największych kłopotów z pracą Katarzyny Wrzesińskiej. Jej autorka zdaje się zakładać, że endecki nacjonalizm to pewien twór obiektywny; zrodził się jako odpowiedź na uwarunkowania kulturowe i polityczne przełomu XIX i XX w. Powstał jako coś właściwego dla danej społeczności. Tymczasem faktycznie był tylko jedną z propozycji rozumienia narodu, które pojawiły się na ówczesnym rynku idei. Jak na dłoni widać ten pluralizm wśród "głosowych” sporów. Endecki nacjonalizm nie był ani jedyną, ani bardziej „narodową" czy też „patriotyczną” formą określenia swojej tożsamości zbiorowej niż inne.

Z tak przyjętego sposobu patrzenia na formację nacjonalistyczną wynikają dalsze konsekwencje. Tylko w takim ujęciu można starać się zrozumieć językowe potworki, które autorka tworzy, by opisać istotę nacjonalistycznego oglądu rzeczywistości w rodzaju „ponaddzielnicowego polskiego oglądu rzeczywistości” (Wrzesińska, 2012, s. 281). I tak, dla przykładu, autorka powtarza i zarazem autoryzuje szereg nieprawdziwych, obiegowych, podszytych albo megalomanią narodową, albo już nienawiścią i pogardą dla całych narodów - jak to często bywało u Romana Dmowskiego - sądów i frazesów. Wrzesińska pisze: „za znamienny typowo rosyjski rys uważano brak moralności” (Wrzesińska, 2012, s. 264). Co sama potem komentuje: „te opinie nie były całkowicie bezpodstawne” (Wrzesińska, 2012, s. 264). Wiele tych sądów leży na cienkiej granicy między ignorancją a zaślepioną wrogością. Jak bowiem ocenić pozostawione w zasadzie bez odautorskiego wyjaśnienia zdania w rodzaju: „kultura niemiecka deformowała duszę i umysłowość polską, pozbawiając ją polotu, oferując w zamian ciasny materializm życiowy, brutalną bezinteresowność" (Wrzesińska, 2012, s. 279)?

Odrębne miejsce zajmuje w książce Wrzesińskiej stosunek wczesnej Narodowej Demokracji do grup mniejszościowych. Publicystyka endecka, także z tego wczesnego okresu, miała na swoim koncie spory dorobek w dzieleniu Polaków na „prawdziwych” i „fałszywych”. Antysemityzm, choć bez wątpienia kluczowy, był przecież tylko częścią szerszego zagadnienia ksenofobicznych narracji mitotwórczych, których endecja była czołowym kreatorem. Jak się wydaje, w tym aspekcie autorka miała trudność w rozróżnieniu ideologicznej warstwy retoryki ksenofobicznej od jej wartości informacyjno-analitycznych. Stąd w pracy zamiast rzetelnego rozbioru retoryki endeckiej tego czasu - częste wycieczki w dość jałowe rozważania, kiedy Narodowi Demokraci okazali się profetami, a kiedy się mylili.

W zasadzie po lekturze omawianej książki trudno pojąć, co stanowiło osnowę, a co osobliwości polskiego nacjonalizmu na tle innych nacjonalizmów w Europie przełomu XIX i XX wieku. Autorka prawie w ogóle nie wyróżnia zaborczych dążeń polskiego nacjonalizmu, nie dostrzega jego retorycznej przesady w kreśleniu wizerunku Rosjan czy Niemców, nie odnotowuje świadomych, lub nie, zapożyczeń, jakie ujawniały się w endeckiej retoryce. Na boku nawet pozostawia radykalny antysemityzm tej formacji. Jako bezrefleksyjną prawdę uznaje endecki dogmat, że konflikt i hegemonia w polityce są naturalnym elementem rzeczywiści społecznej. 
Jedyny godny uwagi akcent w wywodzie autorki to uznanie, że projekt endecki narodził się w samoobronie wobec agresywnego nacjonalizmu sąsiadów, co jest zresztą sądem tak ugruntowanym w literaturze przedmiotu, że w zasadzie banalnym. Badaczka poruszając się po przetartych już szlakach, rzadko podejmuje wysiłek dodania nowych wątków lub poszerzenia katalogu pytań badawczych, jakby straciła wiarę, że warto od nowa wracać do tematu. Uznanie wszak, że u źródeł ekskluzywnego nacjonalizmu, wojującego antysemityzmu połączonego niejednokrotnie z germanofobią i specyficznym orientalizmem - czego świadectwa autorka zresztą skrupulatnie dokumentuje i co sama określa jako „mentalność endecką” - leży walka o ludzką godność, o poszanowanie prawa jednostki i praw zbiorowych grupy narodowej, a także realizacja pełni człowieczeństwa, to już chyba jednak przesada.

Trudno więc przy okazji książki Katarzyny Wrzesińskiej mówić o jakimś znaczącym poszerzeniu pola obserwacji i wrażliwości na fenomen Narodowej Demokracji w polskiej kulturze przełomu wieków. Tym bardziej ciężko uznać, że praca oferuje jakiś nowy komplet narzędzi do analizy problemu.

Jak można sądzić, omawiana praca powstała z intencją powrotu do rzeczy pochopnie lub niesprawiedliwie zapoznanych. Bardzo często wszak przykłady, które autorka przywołuje, oderwane są od kontekstu, w którym zostały wypowiedziane. Pisząc o krytyce kultury bierności - temacie istotnym i faktycznie wielokrotnie podejmowanym w nacjonalistycznej publicystyce przełomu wieków - autorka przywołuje „optymistyczną wizję dziejów narodu polskiego, by wykazać, że jest on nadal zdolny do wielkich czynów". Jako przykład takiej optymistycznej wizji... podaje jedną z najbardziej agresywnych w swej antysemickiej wymowie broszur z epoki bojkotu Żydów w 1912 roku autorstwa Antoniego Marylskiego, Dzieje sprawy żydowskiej w Polsce (Marylski, 1912; por. Wrzesińska, 2012, s. 189).

Bez wątpienia dla takiego wizerunku endecji pomocny okazał się obraz państw zaborczych, który na użytek swojej pracy stworzyła, czy raczej zapożyczyła z epoki, autorka. Niestety także i w tych ustępach razi nadużywanie pustych generalizacji, anachronizm, zestawianie rzeczy nieporównywalnych, często wiodące na ahistoryczne bezdroża. O Drugiej Rzeszy Niemieckiej Wrzesińska pisze: „Niemcy - już nawet nie rząd - w walce ze społeczeństwem polskim chwycili za broń przedtem niedopuszczalną, bo godzącą w zasadę prywatnej własności, która tworzyła ważną podstawę ustroju państwa. Świadczyło to o determinacji rządu i chęci przyspieszenia ostatecznej likwidacji prob le mu polskiego [podkreślenie G.K.]" (Wrzesińska, 2012, s. 285). Inną rzeczą jest to, że sam fenomen integralnego nacjonalizmu $\mathrm{w}$ takim ujęciu zostaje pozbawiony wszelkiego sensu. Oczywiście, Narodowa Demokracja przełomu wieków nie była monolitem, ale także i tego nie widać u Wrzesińskiej. Czego więcej zabrakło w tej złagodzonej i jakże empatycznej dla wczesnych „narodowych demokratów” charakterystyce - nie trzeba chyba więcej wyliczać.

Podsumowując: autorka tworzy coś w rodzaju mitu poczciwej, „dobrej” wczesnej endecji, a więc hagiograficznej opowieści o grupie idealistów, kameralnej wspólnocie 
intelektualistów złączonych wspólnym celem, którzy w warunkach masowej polityki zmienili się nie do poznania. Badaczka w zasadzie zdaje się nie dostrzegać, że monizm aksjologiczny, od którego wyszła Narodowa Demokracja, stanie się w końcu zaczynem wojny domowej. Natomiast otwarcie, z premedytacją, wręcz manifestacyjnie demonstrowana ksenofobia okaże się oznaką wykluczenia z polskości wszystkich nieodpowiadających tej wizji. Ten rozziew między okrągłymi zwrotami a brutalną retoryką nie był przypadkowy. Bo przecież etapy marginalizowania z życia publicznego „nieprawdziwych Polaków”, czy też według określenia Dmowskiego z 1902 roku: „pół-Polaków, którzy muszą zginąć", i inne tego rodzaju rytualne seanse nienawiści z przełomu XIX i XX wieku nie zaczęły się od mniejszości narodowych.

Do tego rodzaju zabiegu interpretacyjnego potrzebna autorce była szczególnego rodzaju akrobacja, czyli wyrzucenie poza nawias prawdziwego dorobku endecji, a zajmowanie się frazesami i zaklęciami o nowoczesności narodu, modernizacji czy deklaracjami o prawdziwej lub fałszywej miłości do własnej wspólnoty - całą dekoracją, w której tak lubują się endeccy apologeci. Wszystko to odbyło się w znanym schemacie dumnego narodu odwiecznie krzywdzonych, szlachetnych i cywilizowanych Polaków otoczonych morzem wrogów: z Zachodu napierających anty-kulturalnych, germańskich barbarzyńców, ze Wschodu zaś prawosławnej, ale przede wszystkim azjatyckiej, zdemoralizowanej ciemnoty. Osobliwie, jak silnie w tym wywodzie pobrzmiewają inteligenckie wyobrażenia o prostych ludziach, „mas[ach] słabo jeszcze wykształconych, szukających łatwych rozwiązań, prostych wskazań, podziału na białe i czarne" (Wrzesińska, 2012, s. 211), które rzekomo znieprawiły „poczciwych”, czyniąc z niepokornych „inteligentów” agresywnych ksenofobów.

Całość wywodu zatem niestety zaciemnia obraz epoki i blokuje postawienie prawdziwych pytań badawczych, pozostawiając nawet na boku kwestię uwalniania się od tego toksycznego dziedzictwa. W omawianej pracy widać zastygnięcie w znanych już, przede wszystkim publicystycznych odczytaniach. Epistemologicznej naiwności i bezradności wobec tekstu i retoryki nie wyrówna jednak nawet bezsprzeczna erudycja autorki. Szkoda.

\section{Bibliografia:}

Marylski, A. (1912). Dzieje sprawy żydowskiej w Polsce. Warszawa: Gebethner i Wolff.

Wrzesińska, K. (2012). Kultura i cywilizacja w myśli Narodowej Demokracji (1893-1918). Między ideą wychowania a polityką. Warszawa: Instytut Slawistyki PAN, Fundacja Slawistyczna. 
Grzegorz Krzywiec, Review of a book by Katarzyna Wrzesińska, Culture and civilization in the thought of National Democratic Party (1893-1918). Between the educational idea and politics, Warszawa: Instytut Slawistyki PAN, Fundacja Slawistyczna 2012, pp. 377.

Abstract: The book by Katarzyna Wrzesińska, a historian of ideas and Polish political thought of the $19^{\text {th }}$ and $20^{\text {th }}$ centuries, a researcher of the Institute of Slavic Studies of the Polish Academy of Sciences, has an ambitious aim to deal with cultural politics of National Democracy, the largest political movement in the history of Polish lands, at the fin-de-siècle. The further themes are, among others, definitions of nation and folk in the nationalist framework, the role and place of educational ideas in a wider scope of the nationalist project, an influence of nationalist ideas on the Polish intelligentsia.

Interestingly, Wrzesińska does not correspond with current social sciences debates about definitions and understandings of nationalisms in literature, but tries to step outside them altogether. Undoubtedly, such a new framework would have helped us move forward in studies on Polish nationalism. Paradoxically though, while the book analyzing a wide array of published primary documents, it offers, in the end, a well-known and conventional story on 'young idealist' debouched whether by mass-politics or by masses as such. The rhetoric of nationalism is quite evident but not equally obvious from Wrzesińska's presentation are the ways in which people appropriated that vocabulary and those ideas for their own ends. The author gives then another casual tale on an innocent but cultural nation and, first and foremost, its elites beset by brutal and uncivilized enemies. Epistemological naiveté, surplus of not analyzed details and quotations, and, last but not least, rather surprisingly narrow catalogue of questions does not address how and why the Polish integral nationalists differed from other national strains of this time.

All in all, unfortunately, the book does not help to capture the complexity of National Democracy in the Polish history of the period under discussion. Not only it does not substantially extend our knowledge on the subject, but as well obscures and blocks serious questions about this political movement and its toxic legacy.

Keywords: cultural politics; National Democracy; Polish nationalism; mass politics

This is an Open Access article distributed under the terms of the Creative Commons Attribution 3.0 PL License, which permits redistribution, commercial and non-commercial, provided that the article is properly cited. www.creativecommons.org/licenses/by/3.0/pl

(c) The Author(s) 2014/2015

Publisher: Institute of Slavic Studies PAS [Wydawca: Instytut Slawistyki PAN]

DOI: 10.11649/slh.2015.017

Author: Grzegorz Krzywiec, Instytut Historii PAN, Warsaw

Correspondence: gkrzywiec@ihpan.edu.pl

The work has been prepared on author's own expense.

Competing interests: No competing interests has been declared. 